\title{
MEMIKIRKAN ULANG BISNIS MODEL BERBASIS DESAIN KOMUNIKASI VISUAL
}

\author{
Mendiola B. Wiryawan \\ Jurusan Desain Komunikasi Visual, Fakultas Komunikasi dan Multimedia, BINUS University \\ Jl. K.H. Syahdan No. 9, Kemanggisan, Palmerah, Jakarta Barat 11480 \\ mendiola@mendioladesign.com
}

\begin{abstract}
Graphic design as an applied art started to grow side by side with the growth of many businesses that needed promotion and advertising. Although graphic design can be categorized as a service company, it cannot be directly handled the same as any other service companies. Design companies always involve two opposite poles: aesthetic vs. logic, individual vs. mass, idealism versus reality. The best way viewing a graphic design as a business entity is seeing through its business model's side. A business model is a simple representation of the complex reality of a business. The primary purpose of a business model is to communicate business mechanism among stakeholders. The article gives insight to see components of graphic design business and their future challenge. In the future, it is expected there are more discussions about this topics so that Indonesian graphic design industry will grow in the future.
\end{abstract}

Keywords: graphic design, industry, corporate, business model

\begin{abstract}
ABSTRAK
Desain grafis sebagai seni terapan mulai tumbuh seiring dengan bertumbuhnya dunia usaha di Indonesia yang memerlukan jasa periklanan dan promosi. Meskipun perusahaan berbasis desain dapat dikategorikan perusahaan berbasis jasa, penanganannya tidak dapat serta merta disamakan dengan perusahaan jasa. Perusahaan desain melibatkan dua kutub yang berbeda: rasa (estetika) versus logika, individual versus massa, idealisme versus realita. Untuk membedah usaha desain grafis dalam bentuk entitas bisnis, cara terbaiknya adalah melihatnya dari kacamata bisnis model. Bisnis model adalah representasi sederhana dari realita yang kompleks sebuah bisnis. Tujuan utama dari bisnis model untuk mengomunikasikan mekanisme bisnis kepada semua stakeholders. Tulisan ini memberi insight awal dari komponen model bisnis desain grafis/komunikasi visual dan tantangannya. Diharapkan lahir diskusi dalam bentuk forum yang lebih luas untuk mengembangkan topik ini, sehingga industri desain khususnya desain grafis dapat lebih berkembang di masa depan.
\end{abstract}

Kata kunci: desain grafis, industri, korporasi, model bisnis 


\section{PENDAHULUAN}

Zaman memang terus berubah, mengalir seperti sungai. Heraclitus di dalam ungkapan pernah berkata: "You could not step twice into the same river; for other waters are ever flowing on to you." Dari perkataannya ini, beliau ingin mengungkapkan bahwa dalam hal yang terlihat tidak berubahpun terdapat perubahan di dalamnya. Perubahan juga tak terelakan di dalam dunia keprofesian, khususnya desain grafis. Hal yang sukses di masa yang lalu mungkin tidak dapat lagi diterapkan di masa sekarang. Seringkali penulis mendengar keluhan dari rekan-rekan seprofesi, terutama dari kalangan yang lebih senior. Mereka menyimpulkan keadaan dulu jauh lebih baik karena dengan lebih mudah dapat 'menjual' desain dengan lebih layak dan lebih cepat.

Terlepas dari banyak faktor lain yang membuat hal ini terjadi, faktor persaingan menjadi satu hal yang perlu digarisbawahi. Dari lebih 12394 mahasiswa/i aktif di program studi DKV pada semester setiap genap 2009. Jika kita asumsikan setiap semester jumlah mahasiswa kira-kira sama dan menghasilkan 10\% kelulusan saja, maka ada lebih dari 2400 kelulusan tiap tahunnya. Dari begitu banyaknya lulusan yang dihasilkan tentunya supply professional menjadi banyak dan beragam. Sebenarnya demand dari pengguna jasa desain pun bukanlah tidak bertumbuh. Jasa desain grafis komunikasi visual dibutuhkan dalam setiap bidang yang membutuhkan promosi dan komunikasi massa.

Seiring bertumbuhnya ekonomi, bertumbuhlah pula tingkat harapan, tingkat kebutuhan, dan tingkat hidup lainnya yang menyebakan meluasnya spektrum tingkat kebutuhan terhadap jasa desain grafis dalam berbagai level. Ekspektasi level yang berbeda antara suply dan demand inilah yang menimbulkan kekecewaan banyak pelaku bisnis desain grafis, karena apa yang diharapkan tidak selalu sesuai dengan kenyataan. Seringkali usaha desain grafis hanya mempertahankan preposisi nilai lama, tanpa memberikan inovasi di dalamnya. Desain Grafis yang berakar dari kata Grafika memang diawali dari seni terapan pada media cetak.

Namun tidak sedikit untuk memenangkan persaingan yang ada, desain grafis juga bermetamorfosis ke bentuk yang lebih kompleks dan cair dari sekedar menyediakan jasa desain yang berbasis media (terutama cetak). Sebutlah sekarang ada branding, web content, digital video, yang sebenarnya masih mengusung nilai desain grafis di dalamnya. Perubahan teknologi dan mudahnya akses kepada aplikasi teknologi seperti penggunaan piranti lunak mendorong desain grafis menemukan bentuk-bentuknya yang baru. Seperti dikatakan Andrew Blauvelt, desain grafis saat ini seperti kehilangan tubuhnya yang utuh karena telah mencair dengan banyak disiplin lain seperti programming, marketing, branding, komunikasi, management, produksi dsb (Blauvelt, 2003). Hal ini membuat bisnis model desain grafis juga berubah. Misalnya dari sisi revenue stream model terdapat perkembangan dari sekedar usage fee model menjadi retainer fee, dan bahkan model lainnya.

Meskipun telah lahir bentuk-bentuk baru yang lebih sophisticated di dunia desain grafis, kita dapat melihat ada hal-hal prinsip yang tidak berubah, yang menjadi komponen utama usaha desain grafis dalam bentuk apapun. Helfand (2003), seorang pakar pendidikan desain pernah menyampaikan: Graphic Design is a 'visual language' uniting harmony and balance, color and light, scale and tension, form and content. But it is an idiomatic language, a language of cues and puns and symbols and allusions, of cultural reference and perceptual inferences that challenge both the intellect and the eye. Definisi ini selalu tersirat di dalam perusahaan yang menawarkan solusi desain grafis kepada kliennya.

Sebagai perseorangan pun, desainer harus menambah kapasitasnya dengan bidang-bidang terkait agar memiliki advantage value. Kini seorang desainer tidak bisa hanya memiliki kemampuan mendesain semata. Oleh karenanya pengetahuan desainer akan sebuah bisnis model dapat menjadi nilai tambahnya dalam menjalankan bisnis (hybrid designer). 
Dalam konteks sederhana, bisnis model dapat diibaratkan sebagai sistem pencernaaan di dalam tubuh. Tanpa asupan dan pengeluaran yang baik tubuh kita akan menjadi sakit. Seringkali orang awam menilai kesehatan sebuah bisnis hanya dari 'yang tampak di luar' layaknya melihat keadaan tubuh dari yang tampak di luar. Brand image yang terlihat baik langsung dan diterjemahkan menjadi bisnis yang baik. Kita sering mendengar perkataan: "Karyawannya banyak, bisnisnya pasti bagus!”Atau perkataan lain seperti: "Proyek yang ditanganinya besar-besar nilainya, pasti bisnisnya bagus!”

Brand, yang adalah persepsi, dan bisnis adalah dua sisi mata uang yang berbeda. Brand yang baik belum tentu mendukung bisnis yang baik. Sebagai contoh kita baru saja dikejutkan oleh satu perusahaan penerbangan terkenal nasional Mandala yang gulung tikar. Ini membuktikan bahwa brand yang baik belum tentu mendukung kinerja bisnis yang baik. Juga menurut Collins (2001), dalam sebuah perusahaan yang baik, profit dan arus kas seperti darah dan air dalam tubuh; mereka sangat esensial di tubuh, tapi bukan poin terpenting dari kehidupan.

Pertanyaan selanjutnya adalah apakah kategori bisnis yang baik? Saya pikir jawabannya akan sama dengan filosofi: apakah itu kehidupan yang baik? Bisa saja orang berkata bisnis yang baik adalah yang menghasilkan jumlah pemasukan tertentu, atau memberi pengaruh tertentu kepada lingkungannya. Bisa juga dikatakan bisnis yang baik akan ada di mana-mana, mendunia, atau hanya fokus di satu tempat. Namun dalam konteks tulisan ini saya menggaris bawahi bisnis yang baik sebagai bisnis yang mampu bertahan secara sustainable. Sustainable disini bukan seluas konteks green business, sebagaimana bisnis yang peduli pada keberlangsungan lingkungan hidup, tetapi lebih kepada bagaimana membuat bisnis yang lebih memiliki usia yang panjang sebagai sebuah entitas, bukan hanya menghasilkan keuntungan sesaat dan punah. Untuk menjadi sustain diperlukan konteks sistem yang dapat bekerja secara terus menerus. Konteks sustainable ini adalah salah satu parameter sebuah bisnis bisa dinilai secara tangible (valuation) dengan tinggi. Banyak perusahaan berbasis desain komunikasi visual tidak dapat dinilai secara bisnis karena lebih merupakan bentuk self employee meskipun memiliki pegawai yang banyak. Salah satu cirinya adalah ketika pemilik perusahaan tidak ikut dalam bisnis seluruh anak buah tidak mampu bekerja karena sangat tergantung kepadanya.

Jadi bagaimana membuat sebuah perusahaan berbasis desain komunikasi visual dapat bekerja lewat sebuah sistem yang baik adalah tujuan dari dihadirkannya tulisan ini. Jika sebuah entitas bisnis itu diibaratkan sebagai sebuah bangunan, dan kita ingin membangun bangunan yang baik, maka perlu diperhatikan banyak hal seperti: materialnya, strukturnya, teknologinya, skill-nya, keadaan sekitar. Tulisan ini ibarat analisa material untuk membangun sebuah bangunan entits bisnis desain grafis. Dalam jurnal ini akan disajikan analisa bisnis model perusahaan desain grafis berdasarkan 9 blok sebagai struktur dari setiap bisnis model.

\section{METODE}

Metode penelitian tulisan ini berdasarkan studi empiris, observasi lapangan, studi literatur, dan wawancara dari berbagai sumber. Penulis membandingkan data-data primer dan sekunder yang ada dalam membentuk hipotesa konsep bisnis desain grafis.

\section{PEMBAHASAN}

Menurut buku Business Model Generation oleh Osterwalder \& Pigneur (2010), ada 9 buah komponen yang membangun sebuah bisnis yaitu: (1) segmentasi pelanggan, (2) proposisi nilai, (3) kanal, (4) relasi pelanggan, (5) arus pemasukan, (6) sumber-sumber kunci, (7) kegiatan kunci, (8) hubungan kunci, dan (9) struktur biaya. 


\section{Segmentasi Pelanggan}

Segmentasi Pelanggan adalah pembagian segmen yg dituju oleh suatu organisasi bisnis dalam menyediakan jasa atau produk yang dituju. Sebuah organisasi perusahaan dapat membagi segmentasi pelanggannya agar tetap mampu memberikan layanan yang baik kepada konsumennya. Pembagian ini dapat dipilah berdasarkan: (1) konsumen membutuhkan produk atau layanan yang sangat berbeda; (2) konsumen harus dijangkau lewat kanal distribusi (distribution channel) yang berbeda; (3) konsumen membutuhkan pendekatan hubungan yang berbeda; dan (4) konsumen mau membayar penawaran yang berbeda.

Banyak perusahaan berbasis desain grafis tidak mampu memilah dengan tepat siapa konsumen mereka sebenarnya. Konsumen diidentifikasikan sebagai siapapun yang membutuhkan usaha ini. Akibat dari tidak jelasnya komponen market usaha ini maka channel yang dibangun tidak tepat tujuan. Hal ini dapat berakibat fatal kepada hal-hal lain. Misalnya pada strategi harga, kita tidak mampu menyusun sebuah strategi harga yang konsisten dan sesuai market karena kita tidak dapat menentukan economic value ataupun pocket size dari khalayak kita.

Masalah lain akibat tidak terdefinisinya market yang jelas adalah masalah komunikasi bisnis. Sebuah entitas bisnis yang baik dibangun karena adanya established network. Network yang baik harus diciptakan dan dibangun lewat komunikasi yang fokus dan terus menerus kepada khalayak yang tepat. Tanpa adanya segmentasi pelanggan yang fokus, komunikasi bisnis tidak efisien dan efektif dari segi waktu dan budget karena kita tidak mungkin berbicara dengan siapapun. Perusahaan desain yang berhasil bertahan biasanya mempunyai segmented market yang jelas dan dapat memberikan pelayanan yang baik kepada segmen yang dituju. Untuk itu komponen segementasi yang tepat merupakan langkah awal dari sustainability sebuah perusahaan desain grafis.

\section{Proposisi Nilai}

Proporsi nilai adalah nilai yang ditawarkan kepada pelanggan dalam menyelesaikan masalah dan memuaskannya. Beberapa komponen proposisi nilai yang mungkin ditawarkan perusahaan desain grafis: (1) service performance, (2) customize, (3) status, (4) aksesibilitas, (5) harga, dan (6) risk reduction.

Service performance adalah preposisi nilai yang dilahirkan karena pelanggan merasa puas akan kemampuan penyedian jasa sebuah entitas bisnis. Dalam konteks perusahaan desain grafis dapat berupa desain yang dianggap bagus atau cocok dengan pelanggan, atau dapat juga ketepatan waktu dalam memberikan layanan jasa.

Customize adalah preposisi nilai dari pemberian pelayanan jasa yang khusus, tidak terdapat di tempat lain. Pada dasarnya jasa desain grafis lebih cenderung memberikan preposisi nilai ini di setiap pekerjaan. Setiap pekerjaan dianggap sebuah pekerjaan 'baru' yang terlepas dari pekerjaan-pekerjaan sebelumnya. Customize di satu sisi memberikan nilai tambah untuk konsumen, namun di sisi managemen bisnis perusahaan kadang menjadi bumerang sebuah perusahaan desain untuk membesarkan dirinya (scaleable). Saya menggaris bawahi penyebabnya: (1) karena proses yang kebanyakan customize, waktu untuk mengerjakan sebuah projek desain menjadi berbanding lurus dengan jumlah pekerja. Akibatnya usaha desain grafis menjadi usaha yang padat karya. Dari studi lapangan, seringkali perusahaan menambah pekerja di saat proyek sedang ramai, namun tidak mampu dengan cepat mengurangi pekerja saat pekerjaan sedang sepi. (2) Karena customize melibatkan craftmenship yang tinggi, setiap pekerjaan membutuhkan touch khusus dari orang-orang tertentu. Akibatnya kadang sulit mendelegasian pekerjaan kepada layer pekerja di bawahnya sehingga seorang desainer utama tidak bisa menambah kapasitas pekerjaannya lebih dari waktu yang dia milliki. 
Status merupakan preposisi nilai yang dapat menjadi advantage value sebuah perusahaan desain dibanding perusahaan lainnya. Mengapa orang mau membeli sesuatu yang lebih mahal dengan kualitas tidak jauh berbeda (ataupun minimal sama)? Salah satunya adalah karena nilai status di dalamnya. Oleh karena apa yang ditawarakan perusahaan desain biasanya adalah customize, nilai status menjadi hal yang penting untuk meningkatkan value of money dari sebuah desain. Sayangnya kebanyakan desainer kurang memperhatikan pembangunan komunikasi brand perusahaan sehingga company brand mudah sekali hilang ditelan jaman. Di lain pihak ada juga yang membangun brandnya di ranah yang salah, tidak di dalam market yang dituju malah membangunnya di ranah kompetitor, yaitu hanya di antara pemain industri sendiri. Proses branding yang membutuhkan effort yang fokus, konsisten, dan gigih, serta memerlukan strategi, taktik, dan manajemen yang baik yang terencana.

Aksesibilitas merupakan sebuah preposisi nilai yang disebabkan karena kesempatan yang diberikan kepada konsumen untuk mengakses sebuah kesempatan tertentu. Seperti sudah disinggung di atas kini bisnis desain grafis mengalami pengembangan lebih dari sekedar menyediakan jasa pembuatan desain berdasarkan pesanan. Aksesibilitas dapat menjadi advantage value untuk perusahaan desain grafis dalam memenangkan persaingan. Aksesibilitas apa yang bisa ditambahkan dalam usaha desain grafis? Misalnya usaha desain grafis dapat membundel jasa dengan barang atau kesempatan tertentu untuk masuk di media atau channel tertentu.

Harga yang relatif lebih murah cenderung menarik perhatian konsumen. Seringkali strategi harga murah merupakan jalan terakhir untuk memenangkan persaingan bisnis. Penggunaan strategi ini tanpa memikirkan masak-masak dampak terhadap kelangsungan bisnis dapat berbahaya. Strategi pemotongan harga harus dibuat sebagai bagian dari promosi, bukan merupakan sesuatu yang long term. Dalam strategi harga, biasanya harga yang murah didasarkan pada kemampuan efisiensi. Karena komponen harga terbesar dari bisnis desain grafis adalah sumber daya manusia, perlu dilakukan kajian dalam melakukan efisiensi kerja. Efisiensi waktu adalah salah satu hal yang perlu diperhatikan. Waktu di sini bukan hanya mengacu pada efisiensi waktu dalam studio, tapi juga harus diperhatikan interval dan jangkauan waktu setiap projek.

Ketika sebuah perusahaan memutuskan untuk bekerjasama dengan perusahaan tertentu, mereka pasti berpikir untuk mengurangi resiko kegagalan mereka di area tertentu. Hal inilah yang juga mendasari kerjasama dengan sebuah perusahaan desain grafis. Mengapa perusahaan lokal multinasional mengadakan tender (pitching) untuk membuat logo mewajibkan pesertanya untuk mempunyai kualifikasi: pernah mengerjakan projek sejenis dengan nilai yang sama di dalam atau luar negri? Hal ini seringkali dikeluhkan perusahaan desain lokal yang kalah pitch ketika menghadapi perusahaan multinasional. Kita harus menyadari bahwa hal ini bukanlah mengenai nasionalisme atau non nasionalisme. Ini adalah soal manajemen resiko. Untuk itu risk reduction harus menjadi bahan pertimbangan yang penting dalam membuat sebuah rencana bisnis.

Perusahaan yang mampu memberikan beberapa value preposition yang terintegrasi akan memiliki kesempatan lebih untuk membangun sustainability company. Salah satu kunci dalam sustainability sebuah perusahaan adalah seberapa besar kemungkinan pembelian berulang oleh pelanggan. Hal ini disebut sebagai recurring model. Salah satu contohnya adalah perusahaan game yang membuat level satu sampai 10, sehingga orang yang sudah main di level satu kemungkinan besar akan membeli level dua dan seterusnya. Ini adalah salah satu strategi yang dapat diterapkan agar value preposition bertambah sehingga arus pemasukan perusahaan bertambah.

\section{Kanal}

Kanal adalah cara atau media yang digunakan perusahaan atau organisasi bisnis dalam mengantarkan proposisi nilai. Channels ini menyangkut komunikasi, distribusi, dan penjualan. Perusahaan desain grafis pada umumnya bersifat Direct Own Channel. Pelanggan langsung ditangani 
perusahaan secara personal. Beberapa perusahaan berbasis desain grafis telah melakukan diversifikasi dengan membangun network dengan perusahaan dengan jasa yang berlainan dan membentuk partner indirect. Hal ini merupakan suatu usaha yang maju, karena bisa merupakan pengembangan jaringan yang efisien. Tantangan berikutnya adalah bagaimana merencanakan koalisi yang mutualisme di antara partner indirect ini.

\section{Relasi Pelanggan}

Semua cara dan media komunikasi yang mencipkan sebuah hubungan yang baik dengan pelanggan. Biasanya perusahaan yang berbasis desain grafis lebih mengandalkan costumer assistance dalam membina hubungan dengan klien. Hal ini sangatlah baik karena hubungan yang manusiawi sangatlah mendasar. Beberapa perusahaan juga telah mengembangkan hubungan ini lewat berbagai media, khususnya media jejaring sosial di internet.

\section{Arus Pemasukan}

Akibat dari proposisi nilai yang berhasil di sampaikan (delivered), pelanggan akan mempunyai hasrat untuk membayar dalam jumlah tertentu sebagai konversi nilai tidak nyata (intangible) ke nilai yang nyata (tangible). Ada beberapa model yang bisa menjadi model revenue stream, yaitu: (1) asset sale adalah biaya yang dikeluarkan pelanggan karena membeli asset tertentu yang berupa produk atau jasa; (2) usage fee, adalah biaya atau charging model karena pelanggan memakai sebuah fasilitas atau kesempatan. Biasanya perusahaan jasa banyak menggunakan metode ini, seperti perusahaan telkom dan hotel; (3) retainer fee adalah biaya yang dikeluarkan pelanggan karena membeli komitmen perusahaan dalam hal termin waktu tertentu untuk melakukan aktivitas tertentu; (4) licencing fee adalah biaya yang didapat dari pemberian hak ekonomi atau hak kekayaan intelektual sebuah asset kepada sebuah perusahaan dalam konteks tertentu; (5) brokerage fee adalah biaya yang didapat dari penjualan asset pihak ketiga karena melalui pihak ke dua.

Dalam bisnis desain grafis konvensional, kebanyakan Revenue Stream datang dari satu sumber yaitu asset sale, dimana jasa (atau yang telah dikonversi ke desain sebagai produk) ditukar dengan nilai finansial tertentu. Untuk pekerjaan yang sifatnya lebih bersifat perhitungan kontrak waktu dapat digunakan reteainer fee. Dalam hal nilai sustainability sebuah perusahaan, retainer fee bisa lebih baik dibandingkan projek-projek yang hanya mengandalkan penjualan asset. Hal ini dikarenakan retainer fee memungkinkan perusahaan untuk melakukan kontrak dengan perusahaan lain dalam kurun tenggang waktu tertentu. Di tengah berkembangnya media, terutama media elektronik, sebenarnya model licencing (biaya yang dikenakan karena penggunaan hak intelektual) bisa dikembangkan di ranah bisnis desain grafis. Contohnya penggunaan simbol atau karakter tertentu. Bahkan brokerage fee, atau exchange fee (biaya yang didapat dari pihak ketiga karena pertukaran dengan barang atau jasa tertentu) bisa juga digunakan dalam bisnis ini. Misalnya penjualan media.

Dalam merancang arus kas juga perlu dipertimbangkan strategi term of payment dan pricing mechanism. Term of Payment yang baik akan memudahkan klien baik secara psikologis ataupun secara finansial. Pricing mechanism mengatur biaya mana yang dapat ditawarkan secara fix ataupun dynamic dalam termin yang telah ditentukan. Fix Fee adalah biaya yang terprediksi yang disampaikan di awal penawaran kerja sebuah proyek desain. Dynamic atau loating fee adalah biaya yang ditentukan setelah klien menggunakan fasilitas atau membeli produk tertentu atau harga yang ditentukan sangat fluktuatif dan tidak dapat ditentukan di awal. Dalam hal penyampaian harga dari pihak ketiga yang tidak pasti, penggunaan usage fee lebih baik diterapkan. Di negara dimana man hour telah begitu dihargai, banyak componen dynamic fee yang diterapkan sesuai dengan kebutuhan pelanggan, seperti waktu meeting, jarak meeting, banyaknya pekerjaan dsb. Di banyak perusahaan desain sering kali dynamic cost tidak diperhatikan sehingga jika dihitung dalam tolak ukur penggunaan waktu versus biaya menjadi tidak efisien. 


\section{Sumber-Sumber Kunci}

Sumber-sumber kunci adalah aset yang dibutuhkan untuk menawarkan dan menyampaikan (over and deliver) elemen-elemen sebelumnya, seperti fisik, intelektual, sumber daya manusia, finansial.

Aset fisik apa yang diperlukan dalam menunjang kegiatan secara langsung kepada keberlangsungan bisnis? Misalnya kantor, kendaraan, dsb. Karena perusahaan desain grafis secara natur adalah perusahaan jasa, biasanya aset fisik lebih untuk menjawab kebutuhan sumber daya manusia internal dibanding untuk menjawab kebutuhan klien. Akibatnya tuntutan 'great office' lebih karena pemenuhan ego team desain. Dari beberapa wawancara dengan prinsipal perusahaan desain diakui bahwa komponen sewa tempat menjadi komponen yang overhead yang tinggi. Untuk menjaga agar komponen sewa properti tidak over budget, disarankan agar komponen ini tidak lebih besar dari $20 \%$ dari total revenue.

Meskipun perusahaan desain sangat bergantung pada kemampuan intelektual sumber daya manusianya, jarang sekali perusahaan yang melengkapi dirinya dengan dokumen-dokumen yang dapat memberikan perlindungan hukum terhadap apa yang mereka hasilkan. Manajemen intelektual dapat juga menjadi perluasan proposisi nilai. Jika hak intelektual bisa dikembangkan menjadi proposisi nilai, maka perusahaan desain dapat berkembang mempunyai kanal baru dalam menghasilkan revenue stream. Setiap entitas bisnis selalu memerlukan sumber daya dengan kualitas tertentu. Bisnis desain grafis memerlukan sumber daya manusia (SDM) yang unik karena sangat dipengaruhi rasa dan karsa dalam menghasilkan proposisi nilai bagi konsumennya. Namun perusahaan yang baik harus tetap dapat menemukan sebuah model kerja yang dapat diprediksi meskipun tetap memperhatikan kaidahkaidah kreativitas di dalamnya. Finansial ibarat bahan bakar dalam keberlangsungan sebuah model bisnis. Untuk itu pengelolaan finansial secara tepat merupakan sebuah keharusan.

\section{Kegiatan Kunci}

Kegiatan kunci adalah kegiatan dalam organisasi perusahaan yang harus diakukan dalam mendukung sebuah usaha bisnis. Dalam sebuah bisnis desain komunikasi visual diperlukan setidaknya diperlukan departemen: Business, Creative, Account Management, Production, Finance. Pengaturan traffic yang jelas lewat Standard Operation procedure (SOP) sangatlah diperlukan. Dalam tiap kegiatan inti ini diperlukan management efisiensi agar perusahaan dapat berjalan dengan tetap optimal. Pertimbangan outsource atau share management menjadi pilihan yang baik agar organisasi tetap kompak dan efisien.

\section{Hubungan Kunci}

Setiap perusahaan tidak mungkin berjalan dengan sendiri. Pengaturan mekanisme partnership perlu dipertimbangkan agar terjadi kesinambungan yang baik dan menguntungkan kedua belah pihak. Misalnya dengan pihak supplier ditentukan model kerjasama, bagaimana sistem pembayaran yang baik, dsb. Contoh supplier adalah freelancer, fotografer, programer, percetakan, dsb.

\section{Struktur Biaya}

Semua elemen di atas akhirnya bermuara di dalam struktur biaya. Efisiensi dan optimalisasi setiap poin di atas akan mempengaruhi struktur biaya yang lebih baik. Dalam jangka menengah dan panjang, biaya harus diatur sedemikian rupa dengan mempertimbangkan economic scale. Managemen fix cost dan floating cost perlu dilakukan agar perusahaan memiliki cash flow yang baik. Semua struktur cost dan revenue akhirnya harus dipertanggungjawabkan di dalam laporan finansial (rugi laba dan neraca). Laporan Keuangan merupakan rapor bagi nilai bisnis sebuah perusahaan. Sebaik dan 
seterkenal apaapun desain sebuah perusahaan tidak akan ada nilainya jika ia tidak mampu membuktikan performa yang baik di dalam laporan finansial.

\section{PENUTUP}

Dari pemaparan di atas, dapat melihat bahwa banyak hal yang perlu diperhatikan ketika kita ingin membangun sebuah perusahaan berbasis desain grafis/desain komunikasi visual. Sisi Brand dan Bisnis tidak bisa dibiarkan begitu saja agar dapat tumbuh dan berkembang. Jika ibaratnya bisnis adalah sebuah permainan, bidang desain grafis yang ingin ikut bermain harus mengikuti kaidah-kaidah dan aturan bisnis yang ada. Seperti sudah disebutkan di atas, sayang sekali banyak sekali perusahaan desain grafis yang gagal karena kekurangmengertian akan wawasan tentang bisnis. Memang diperlukan kolaborasi antara pelaku bisnis dan profesional desainer, karena melakukannya sendiri dengan baik sangatlah sulit. Namun alangkah baiknya jika dari awal semua pihak mengetahui wawasan makro tentang bisnis supaya perusahaan bisa berjalan dengan lebih baik.

Ketika berbicara tentang wawasan dan pemahaman kita harus bicara tentang pendidikan. Pendidikan desain di Indonesia kebanyakan memang berfokus pada thinking dan skill sebagai seorang professional desain grafis. Sayangnya tidak semua lulusan DKV menjadi profesonal desain grafis, namun tidak sedikit lulusan yang memulai usahanya sendiri di bidang DKV menjadi seorang entrepreneur. Untuk menjawab hal ini, beberapa perguruan tinggi yang mencoba melakukan terobosan dengan memberi mata kuliah seperti entrepreneurship, manajemen desain dsb. Namun dari pengamatan penulis, seringkali mata kuliah ini tidak memberi pemahaman mendasar terhadap model bisnis industri desain. Selain itu proporsi satuan kredit semester (SKS) mata kuliah ini yang kecil menyiratkan bahwa mata kuliah ini hanya sebagai pelengkap, bukan sesuatu yang dinilai penting.

Namun hal ini bukanlah berarti serta merta kita perlu menambahkan sks yang banyak kepada mata kuliah ini. Pendidikan DKV tidak boleh terjebak untuk menjadikan peserta didiknya seorang 'Superman' yang menjadi expertis dalam banyak hal dari A-Z; dari konsep, desain, hingga manajemen bisnis, atau keuangannya. Namun mata kuliah yang ada dapat dirancang menjadi sebuah insight yang akan menjadi bekal untuk berkolaborasi dengan pihak-pihak yang dapat memberi touch pada sisi bisnis usaha ini. Dalam sebuah terbitan Business week (Agustus, 2005), majalah ini menyorot tentang kolaborasi disiplin antara sekolah bisnis dengan sekolah desain sebagai sebuah trend pendidikan tinggi dalam melahirkan inovasi baru di perusahaan. Ini merupakan tantangan bagi perguruan tinggi desain di masa depan. Kolaborasi desainer dan profesional bidang-bidang lainnya memang sebuah keharusan, khususnya di bidang bisnis. Namun pemahaman bisnis dapat membantu desainer berkolaborasi dengan baik untuk menjalankan perusahaan desainnya. Akhir kata semoga tulisan ini membantu para entrepreneur yang bergerak di bidang desain grafis dan desain komunikasi visual untuk mengembangkan bisnisnya.

\section{DAFTAR PUSTAKA}

Blauvelt, A. (2003). Towards critical autonomy, or can graphic design save itself? Dalam M. Bierut, W. Drenttel, \& S. Heller (Eds.)., Looking closer 5: Critical writing on graphic design. New York: Allworth Press.

Collins, J. (2001). Good to great: Why some companies make the leap... and others don't. New York: Harper Collins.

Osterwalder, A., \& Pigneur, Y. (2010). Business model generation. New Jersey: John Wiley \& Sons. 


\section{RIWAYAT PENULIS}

Mendiola B. Wiryawan lahir di kota Jakarta pada 22 Januari 1977. Penulis menamatkan pendidikan S1 di Universitas Pelita Harapan dalam bidang Desain Komunikasi Visual pada 2000. Saat ini bekerja sebagai principle di Mendiola Design Associates. Penulis aktif di Asosiasi Desain Grafis Indonesia (ADGI) sebagai Brand Communication Director dan Forum Desain Grafis Indonesia (FDGI) sebagai Pembina. 